 \\ International Journal of Social Sciences and Management
}

\section{A Rapid Publishing Journal}

ISSN 2091-2986

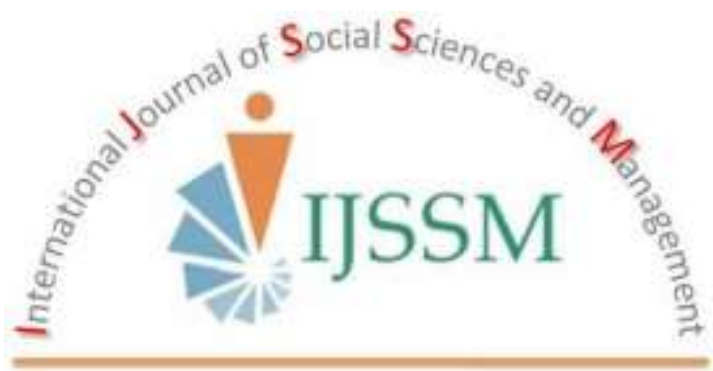

\section{Indexing and Abstracting}

CrossRef, Google Scholar, International Society of Universal Research in Sciences (EyeSource), Journal TOCs, New Jour, Scientific Indexing Services, InfoBase Index, Open Academic Journals Index (OAJI), Scholarsteer, Jour Informatics, Directory of Research Journals Indexing (DRJI), International Society for Research Activity (ISRA): Journal Impact Factor (JIF), Simon Fraser University Library, etc.

Vol- 3(1), January 2016 


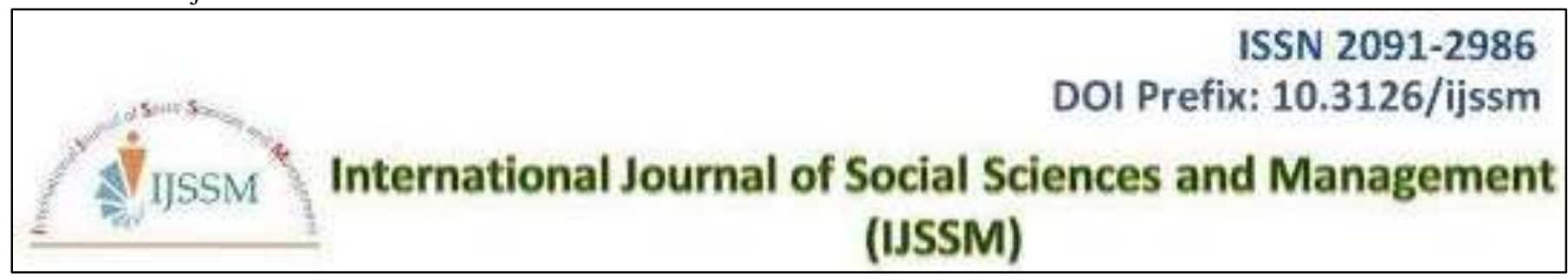

\title{
FACTORS IN THE DISTRIBUTION OF SUCCESSFUL MARRIAGE

\author{
${ }^{1}$ Post Graduate Department of Home Science, Ranchi University, Ranchi-834008, India \\ ${ }^{2}$ ICAR-Indian Institute of Natural Resins and Gums, Namkum, Ranchi-834010, India \\ *corresponding author email: seemadey@rediffmail.com
} \\ Seema Dey ${ }^{* *}$ and Jyotirmoy Ghosh ${ }^{2}$
}

Research Article

\begin{abstract}
Successful marriage is a dynamic growing relationship in which the personalities of both partner continue to develop to achieve personal satisfaction. The earlier the adjustments are made, the more likely is the marriage to be happy and the fewer the areas in which the couples fails to adjust, the better are the chances for happiness in the marriage. The findings of the study revealed that factors that emerged to be important for enhancing marital satisfaction were respect for emotion, attitude towards marriage, expression of love, regard for views and importance to the likings of the spouse, ignoring weaknesses of the spouse, sexual adjustment, temperament, value, taste and interest. The lower ranks of management of time, management of income, technological factors and job related factors reflect that these are not considered serious because couples are already enjoying labour saving and luxury items and frequently go for outings. With respect to conflict resolution avoidance was given higher rank in comparison to arbitration.
\end{abstract}

Keywords: Factors; marriage; satisfaction

\section{Introduction}

Urbanization, industrialization, education, migration and other socio-cultural factors are affecting various aspects of traditional Indian society. After independence due to constitutional provisions, planned economic development, science and technology there has been a great change in the family and society. Women who adopted the ideal-typical role of the working women generally changed their old attitude and developed modern attitudes. Earlier women had faced problem like economic, dependency, male domination, discrimination etc. The modern society gave rise to new problem for women like mal-adjustment, status problem, family crisis, divorce and inter-generational conflict. The relationship between wives' employment and marital satisfaction has changed over the last 30 years. Marital quality (satisfaction, happiness or adjustment) decreased particularly among husbands, when wives were employed outside the home in the 1960s (Burke and Weir, 1976; Orden and Bradburn, 1969). By the 1970s there was no significant difference in marital quality for husbands or wives in families in which the husband was the only wage earner and in two-earner families (Glenn and Weaver, 1978; Locksley, 1980). Satisfaction level was found to be highest among those whose husbands helped in cooking and lower among those who did their cooking alone It was found that small family size, good health, adequate family income and grown up children were the main factor promoting satisfaction level of the working women in respect of their home role performance (Kaur and Punia, 1986). Couple therapy approach placed emphasis upon helping couples to use couple assessment to assist self-evaluation of their relationship's strengths and weaknesses, and to understand the influences that have lead the relationship to take its current form. This understanding is used as the base from which each partner is assisted to identify self- change that can enhance the relationship (Halford, 2001). Forgiveness appears to be especially important in marital relationship. Marital forgiveness is seen as an exciting area for future exploration and one that is ripe with possibility (Fincham et al., 2006). Women seem to be most satisfied with husbands with similar age or older to them by 1 to 5 years. The satisfaction diminishes as the age difference increases (Bernard 1934). Individuals whose spouses were of a different religious persuasion than themselves had been found to report lower levels of marital satisfaction (Ortega et. al., 1988). Hafstrom and Dunsingh (1972) also reported that income acts as a source of power in marital relationship due to higher income, the husband can afford to have other resources which minimize the wife's participation in domestic work. It revealed that there was a significant effect of similar personality traits of the spouses in achieving marital satisfaction. Certain dissimilar temperamental traits also helpful for marital adjustment. Regarding similarity between spouses with regards to value of life is generally found to be conducive to marital satisfaction. Perceived spousal support adequacy uniquely predicts marital quality (Dehle et. al., 2001).

Jharkhand, a mineral rich state, has witnessed fast industrialization in $20^{\text {th }}$ century which picked up after independence. The process of industrialization facilitated 
emergence of subsidiary industries and social infrastructures like, school, college and hospitals. The massive social reforms and awakening programmes undertaken by voluntary organizations particularly Christian Mission helped a lot in socio-economic empowerment of women. Chhotanagpur region of Jharkhand comprises two divisions viz., Ranchi and Hazaribagh where the concentration of industries and voluntary organization is more. The present study was planned to investigate factors in the distribution of successful marriage of working women from different organized sectors.

\section{Materials and Methods}

The study was carried out in four district of Jharkhand state namely Ranchi, Hazaribag, Ramgarh and Bokaro on the basis of representative average of working women in the state. A substantial number of women are employed in industries and social organizations like schools, colleges and hospitals. A total of three hundred respondents were randomly selected- 100 from different professions like education, health and other services. The variables were measured with the help of scales and indices already available as well as developed under this study. The information on socio economic condition of the working women were collected through a specially designed schedule for the purpose and adopted for the survey after needed modification in the light of the requirement of the pre-testing through a pilot study. The data thus collected was systematically classified tabulated and analyzed for drawing the relevant interferences. Conceptual framework of marital satisfaction is shown in Fig. 1.

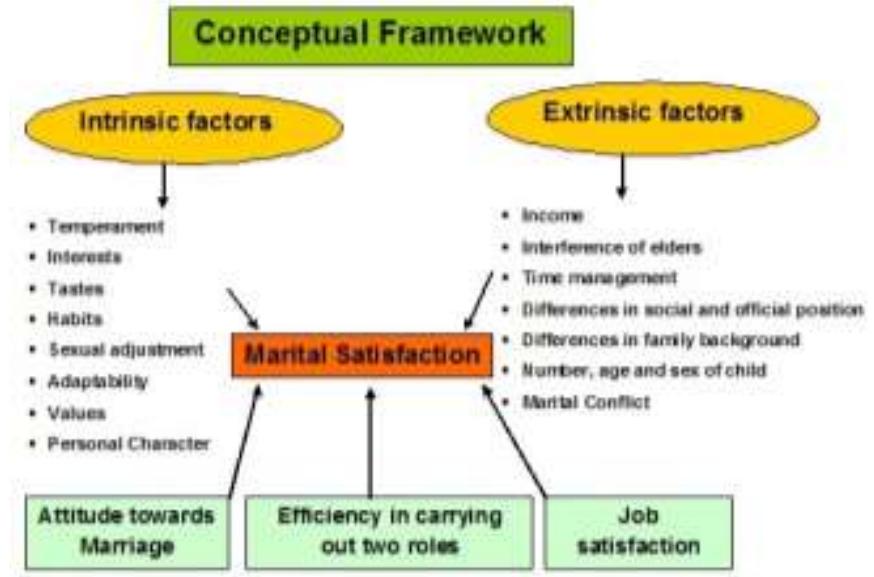

Fig. 1: Conceptual framework of marital satisfaction

\section{Results and Discussions}

\section{Suitable measures for overcoming marital stress and enhancing marital satisfaction}

The importance of this study lies in recommendations for reducing marital stress and enhancing marital satisfaction (Table 1). For this suggestions of the respondents were sought on psychological, personal, social, family ,management of time, management of income, recreational, technological, job related and conflict resolution factors divided into 32 items related with marital satisfaction. The items were ranked on the bases of frequency of the respondents against selected factors.

Doctor gave first rank to adjustment with prioritized work of the spouse followed by respect for emotion, expression of love, regard for views and enjoying leisure time with spouse. Last rank was given to freedom to take part in social and religious activities. Officer rated attitude towards marriage as the most important factor followed by expression of love, respect for emotion, regard for views and sexual adjustment. They gave last rank to refraining from comparing with others. As far as the suggestions of college teacher is concerned, they considered attitude towards marriage as the most important factor followed by expression of love, importance to the likings of the spouse, respect for emotion and ignoring weaknesses of the spouse. For school teacher the factors in descending order of importance were; suitable working hours, respect for emotion, attitude towards marriage, regard for views and leisure time with spouse. In the opinion of clerk, the most important factor was attitude towards marriage followed by removing undue interference of elders, say in decision making, consensus expenditure and consensus savings. They gave last rank to similarities of habits. Nurse placed highest importance on psychological factors. According to them the factors in descending order of importance were; similarities of temperament followed by the factors like value, habits, interest and taste. The responses of different categories of the respondents were aggregated to decide the overall rank of the items. Respect for emotion emerged to be the most important factor followed by attitude towards marriage, expression of love, regard for views and importance to the likings of the spouse, ignoring weaknesses of the spouse, sexual adjustment, temperament, value, taste and interest.

Psycho-personal factors were more important than other factors to reduce marital stress and increase marital satisfaction. It is natural for anybody to expect that one's emotion is respected. The bondage developed out of emotion is the strongest. However, this bond is very sensitive and requires high skills on the part of partners for its sustenance. Spouses could be suggested to respect the emotions of one another on continuous basis. Attitude towards marriage is deeply rooted in traditional values. Favourable attitude lies on elders as well as social and cultural organizations. Love is internal but suggested to express to the maximum possible extent, by presenting gift on appropriate occasion, appreciation, continuous contact if located at distant place, patting, kissing, hugging or any means permitted by the respective culture. Everybody expects regard for ones intellect. Spouses, must respect the views of the partner. 
Table 1: Suggestions for overcoming marital stress and enhancing marital satisfaction

\begin{tabular}{|c|c|c|c|c|c|c|c|c|c|c|c|c|c|c|c|c|}
\hline \multirow{2}{*}{$\begin{array}{l}\text { Respondent } \\
\text { Factor }\end{array}$} & \multicolumn{2}{|c|}{ Doctor } & \multicolumn{3}{|c|}{ Officer } & \multicolumn{3}{|c|}{ College teacher } & \multicolumn{2}{|c|}{ School teacher } & \multicolumn{2}{|c|}{ Clerk } & \multicolumn{2}{|c|}{ Nurse } & \multicolumn{2}{|c|}{ Overall } \\
\hline & $\mathbf{N}$ & $\mathbf{R}$ & $\mathbf{N}$ & & $\mathbf{R}$ & $\mathbf{N}$ & & $\mathbf{R}$ & $\mathbf{N}$ & $\mathbf{R}$ & $\mathbf{N}$ & $\mathbf{R}$ & $\mathbf{N}$ & $\mathbf{R}$ & $\mathbf{N}$ & $\mathbf{R}$ \\
\hline \multicolumn{17}{|l|}{ I Psychological } \\
\hline Interest & 33 & XIII & 31 & & $X$ & 25 & & XI & 28 & XIII & 12 & XXII & 42 & IV & 171 & $X$ \\
\hline Value & 34 & XII & 33 & & IX & 24 & & XII & 27 & XIV & 11 & XXIII & 46 & II & 175 & VIII \\
\hline Temperament & 36 & XI & 35 & & VIII & 26 & & $\mathrm{X}$ & 25 & XV & 10 & XXIV & 48 & $\mathrm{I}$ & 180 & VII \\
\hline Taste & 30 & XIV & 37 & & VII & 22 & & XIV & 36 & VII & 8 & XXV & 40 & $\mathrm{~V}$ & 173 & IX \\
\hline Habits & 4 & XXXI & 40 & & VI & 23 & & XIII & 1 & XXXII & 1 & XXXII & 44 & III & 113 & $\mathrm{XV}$ \\
\hline \multicolumn{17}{|l|}{ II Personal factor } \\
\hline Attitude towards marriage & 28 & XXV & 49 & & I & 47 & & I & 45 & III & 46 & I & 23 & XIV & 238 & II \\
\hline Expression of love & 46 & III & 47 & & II & 45 & & II & 30 & XII & 29 & $\mathrm{X}$ & 27 & XII & 224 & III \\
\hline Respect for emotion & 47 & II & 45 & & III & 40 & & IV & 46 & II & 28 & $\mathrm{XI}$ & 39 & VI & 245 & $\mathrm{I}$ \\
\hline Regard for views & 45 & IV & 43 & & IV & 30 & & VIII & 42 & IV & 27 & XII & 25 & XIII & 212 & IV \\
\hline Importance to liking of the spouse & 41 & VII & 29 & & XI & 42 & & III & 32 & $\mathrm{XI}$ & 26 & XIII & 38 & VII & 208 & $\mathrm{~V}$ \\
\hline Ignoring weaknesses of the spouse & 37 & $\mathrm{X}$ & 27 & & XII & 37 & & $\mathrm{~V}$ & 33 & $\mathrm{X}$ & 25 & XIV & 33 & IX & 192 & VI \\
\hline Sexual adjustment & 38 & IX & 42 & & $\mathrm{~V}$ & 35 & & VI & 22 & XVI & 24 & XV & 31 & $\mathrm{X}$ & 192 & VI \\
\hline Adjustment with prioritized work of the spouse & 49 & $\mathrm{I}$ & 5 & & XXIX & 32 & & VII & 9 & XXIV & 23 & XVI & 29 & XI & 147 & XII \\
\hline Refraining comparing with others & 5 & $\mathrm{XXX}$ & 2 & & XXXI & 27 & & IX & 35 & VIII & 18 & XIX & 35 & VIII & 122 & XIV \\
\hline \multicolumn{17}{|l|}{ III Social factors } \\
\hline $\begin{array}{l}\text { Freedom to take part in social and religious } \\
\text { activities }\end{array}$ & 3 & XXXII & 4 & & XXX & 2 & & XXXI & 20 & XVII & 16 & XX & 21 & $\mathrm{XV}$ & 66 & XXV \\
\hline Freedom to interact with outsiders & 40 & VIII & 3 & & XXXI & 1 & & XXXII & 18 & XVIII & 14 & XXI & 19 & XVI & 95 & $\mathrm{XX}$ \\
\hline \multicolumn{17}{|l|}{ IV Family factors } \\
\hline Removing undue interference of elders & 26 & XVI & 25 & & XIII & 21 & & $\mathrm{XV}$ & 16 & XIX & 44 & II & 15 & XVIII & 147 & XII \\
\hline Say in decision making & 24 & XVII & 24 & XIV & & & XVI & 15 & $\mathrm{XX}$ & 42 & III & 17 & & & XI & \\
\hline
\end{tabular}


Table 1: Suggestions for overcoming marital stress and enhancing marital satisfaction

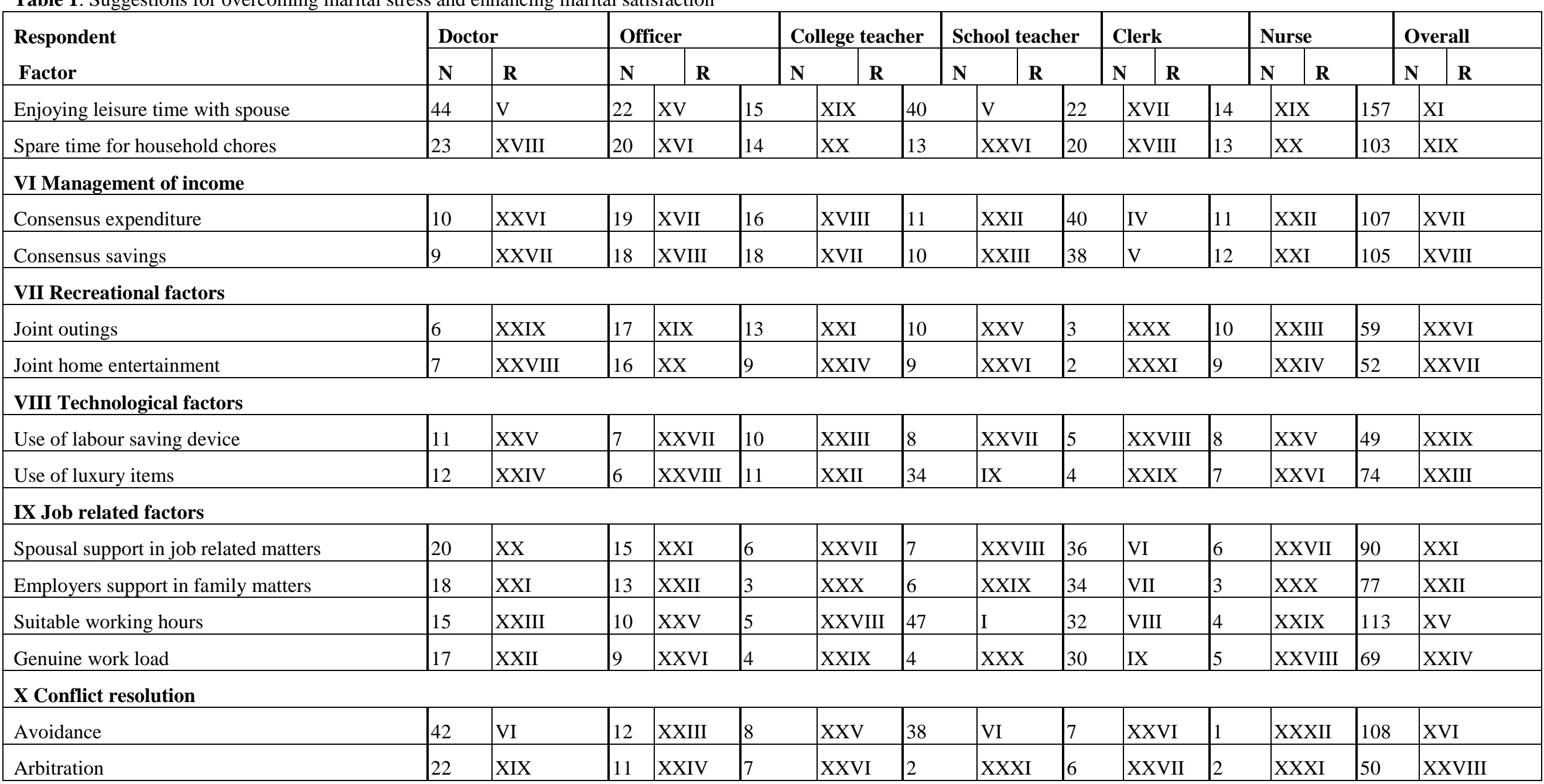


Going by ones likings is natural phenomenon. Partner should be allowed to do the things of one's choice to the permissible limit. If liking is against the society, norms and could not be permitted as per resources available, the matter should be resolved by using intellect and emotions. No person is complete. Everybody has some strong and some weak points. Weaknesses of the partner should be overlooked to the possible extent. At the same time efforts should be made to remove those weaknesses. Sex is the foundation of marriage so care should be taken to ensure sexual adjustment by discussion on sex related issue, sexual extroversion, guessing sexual need of the partner and acting thereupon. Similarities of temperament, value, taste and interest are the favourable factors. If both the partners are ill tempered, the problem will aggravate. Hence, difference is sometimes helpful in marital satisfaction. These psychological factors could be harmonized by manipulation through intelligence and emotions.

\section{Conclusion}

The factors having higher rank were related to psychological and personal characteristics of marriage partners. This gives a clue that satisfaction lies within the partners and positive modification in these factors are sufficient enough to bring about happiness in married life. However, some roles are expected to be played by elders of the family, cultural organizations, employer and government for infusing peace and happiness in the life of the married couple for making a happy society and producing dedicated individuals.

\section{References}

Bernard J (1934) Factors in the distribution of success marriage. American Journal of Sociology, II.
Burke R and Weir T (1976) Relationship of wives' employment status to husband, wife and pair satisfaction and performance. Journal of Marriage and the Family. 38: 279-287.

Dehle C, Larsen D and Landers JE (2001) Social support in marriage [Special issue]. American Journal of Family Therapy, 29(4): 307-324.

Fincham FD, Hall J and Beach SRH (2006) Forgiveness in marriage: Current status and future direction. Family Relations 55(10): 415-427.

Glenn ND and Weaver CN (1978) A multivariate, multisurvey study of marital happiness. Journal of Marriage and Family 40: 269-282.

Hafstrom JW and Dunsing MM (1973) Level of living factors influencing the home maker's satisfaction. Home Economics Research Journal 2: 119-132.

Halford WK (2001) Brief Couple Therapy. New York: Guilford Press.

Kaur S and Punia RK (1986) Performance of and satisfaction from household work. The Indian Journal of Home Science 16 (4): 215-222.

Landis JT and Landis MG (1977) Become a successful marriage ( $7^{\text {th }}$ Ed.) Prentice hall, Inc. Englewood Uniffs, New Jersey.

Locksley A (1980) On the effects of wives' employment on marital adjustment and companionship. Journal of Marriage and Family 42: 337-346.

Orden SR and Bradburn NM (1969) Working wives and marital happiness. American Journal of Sociology 74: 392-407.

Ortega ST, Whitt HP and Williams JA (1988) Religious homogamy and marital happiness. Journal of Family Issues, 9: 224-239.

Sangwan S (2002) Marital adjustment: Effect of personal factors, Indian Journal of Social Research 43(2):107-111. 